\title{
Large Projection Neurons in Lamina I of the Rat Spinal Cord That Lack the Neurokinin 1 Receptor Are Densely Innervated by VGLUT2-Containing Axons and Possess GluR4- Containing AMPA Receptors
}

\author{
Erika Polgár, ${ }^{1}$ Khulood M. Al-Khater, ${ }^{1}$ Safa Shehab, ${ }^{2}$ Masahiko Watanabe, ${ }^{3}$ and Andrew J. Todd ${ }^{1}$ \\ ${ }^{1}$ Spinal Cord Group, Faculty of Biomedical and Life Sciences, University of Glasgow, Glasgow G12 8QQ, United Kingdom, ${ }^{2}$ Department of Anatomy, Faculty \\ of Medicine and Health Sciences, United Arab Emirates University, Alabama-Ain, United Arab Emirates, and ${ }^{3}$ Department of Anatomy, Hokkaido \\ University School of Medicine, Sapporo 060-8638, Japan
}

\begin{abstract}
Although most projection neurons in lamina I express the neurokinin 1 receptor (NK1r), we have identified a population of large multipolar projection cells that lack the NK1r, are characterized by the high density of gephyrin puncta that coat their cell bodies and dendrites, and express the transcription factor Fos in response to noxious chemical stimulation. Here we show that these cells have a very high density of glutamatergic input from axons with strong immunoreactivity for vesicular glutamate transporter 2 that are likely to originate from excitatory interneurons. However, they receive few contacts from peptidergic primary afferents or transganglionically labeled A $\delta$ nociceptors. Unlike most glutamatergic synapses in superficial laminas, those on the gephyrin-coated cells contain the GluR4 subunit of the AMPA receptor. A noxious heat stimulus caused Fos expression in $38 \%$ of the gephyrin-coated cells but in $85 \%$ of multipolar NK1r-immunoreactive cells. These findings are consistent with the suggestion that there is a correlation between function and morphology for lamina I neurons but indicate that there are at least two populations of multipolar neurons that differ in receptor expression, excitatory inputs, and responses to noxious stimulation. Although there are only $\sim 10$ gephyrin-coated cells on each side per segment in the lumbar enlargement, they constitute $\sim 18 \%$ of the lamina I component of the spinothalamic tract at this level, which suggests that they play an important role in transmission of nociceptive information to the cerebral cortex. Our results also provide the first evidence that postsynaptic GluR4-containing AMPA receptors are involved in spinal nociceptive transmission.
\end{abstract}

Key words: spinothalamic tract; gephyrin; NK1 receptor; GluR3; antigen retrieval; multipolar neurons

\section{Introduction}

Lamina I of the dorsal horn is innervated by nociceptive primary afferents and contains many neurons that project to the brain. Projection cells constitute $\sim 6 \%$ of lamina I neurons in midlumbar segments (Spike et al., 2003; Al-Khater et al., 2008), and $\sim 80 \%$ of these express the neurokinin 1 receptor (NK1r) (Todd et al., 2000). The NK1r (which is found on 45\% of all lamina I neurons) (Todd et al., 1998) is the main target for substance $\mathrm{P}$ released by nociceptive afferents (Mantyh et al., 1995; Lawson et al., 1997). We have shown that NK1r-expressing projection neurons in lamina I are densely innervated by substance $\mathrm{P}$-containing primary afferents and that most upregulate Fos after noxious chemical or thermal stimulation (Todd et al., 2002, 2005).

Received Aug. 25, 2008; revised 0ct. 20, 2008; accepted 0ct. 22, 2008.

This work was supported by the Wellcome Trust and the Faculty of Medicine and Health Sciences of the United Arab Emirates University. We thank R. Kerr and C. Watt for expert technical assistance, S. Bennett and K. Hughes for help with some of the experiments, and Drs. Z. Puskár and T. Yasaka for helpful discussion and advice.

Correspondence should be addressed to Andrew J. Todd, Spinal Cord Group, West Medical Building, University of Glasgow, University Avenue, Glasgow G12 80Q, UK. E-mail: a.todd@bio.gla.ac.uk.

D0I:10.1523/JNEUROSCI.4053-08.2008

Copyright $\odot 2008$ Society for Neuroscience $\quad$ 0270-6474/08/2813150-11\$15.00/0
Lamina I projection neurons in cat and monkey can be classified as multipolar, fusiform, or pyramidal (Zhang et al., 1996; Zhang and Craig, 1997). It has been suggested that these have distinctive functional properties, with pyramidal cells responding to innocuous cooling, whereas multipolar and fusiform cells are activated by noxious stimuli (Han et al., 1998). Although the same classes of projection neuron have been identified in rat, we found that most cells in each class expressed NK1r and that there was no difference between morphological types of NK1rexpressing projection neuron in either the density of contacts from substance P-containing afferents or the percentage of cells that upregulated Fos after noxious stimulation (Todd et al., 2002, 2005; Spike et al., 2003).

We have identified a population of large multipolar lamina I projection neurons that lack NK1r but are activated by noxious chemical stimuli (Puskár et al., 2001). These cells have dense inhibitory input and can be identified by the numerous synapses containing the glycine receptor-associated protein gephyrin that coat their somata and dendrites. However, little is known about their excitatory inputs. Glutamatergic synapses in dorsal horn are associated with AMPA receptors (AMPArs), which underlie fast excitatory synaptic transmission (Yoshimura and Jessell, 1990; 
Table 1. Antibodies used in this study

\begin{tabular}{llll}
\hline Antibody & Species & Dilution & Source \\
\hline CGRP & Guinea pig & $1: 10,000$ & Bachem \\
CGRP & Sheep & $1: 5000(1: 50,000)$ & Biomol International \\
CTb & Goat & $1: 5000$ & List Biological \\
Fos & Rabbit & $1: 5000$ & Santa Cruz Biotechnology \\
Fluorogold & Guinea pig & $1: 500$ & Protos Biotech \\
Gephyrin, mAb 7a & Mouse & $1: 1000(1: 100,000)$ & Synaptic Systems \\
GluR3 & Goat & $1: 500$ & M. Watanabe \\
GluR4 & Rabbit & $1: 100-1: 300$ & Lab Vision Products \\
GluR4 & Rabbit & $1: 500$ & Upstate \\
NF200, clone N52 & Mouse & $1: 500-1000$ & Sigma \\
NK1r & Rabbit & $1: 10,000$ & Sigma \\
NK1r & Guinea pig & $1: 1000$ & Biomol International \\
VGLUT2 & Guinea pig & $1: 5000(1: 50,000)$ & Millipore Bioscience Research Reagents \\
VGLUT2 & Rabbit & $1: 5000$ & Synaptic Systems \\
\hline
\end{tabular}

Numbers in parentheses indicate the dilutions of primary antibodies when these were revealed with the tyramide signal amplification method.

(Puskár et al., 2001). All of these animals made an uneventful recovery, and, after $3 \mathrm{~d}$, they were reanesthetized with pentobarbitone $(300 \mathrm{mg}$, i.p.) and perfused with fixative as described above.

Tissue processing and immunocytochemistry. Lumbar spinal cord segments (L2-L5) from all animals were removed and stored in the same fixative at $4^{\circ} \mathrm{C}$ for $5-18 \mathrm{~h}$. Selected segments were then cut into horizontal or transverse 60$\mu \mathrm{m}$-thick sections with a Vibratome. The brains from the five rats that received stereotaxic injections were also removed and cryoprotected, and regions containing the injection sites were cut into $100 \mu \mathrm{m}$ coronal sections with a freezing microtome.

In all cases, spinal cord sections were immersed in $50 \%$ ethanol for $30 \mathrm{~min}$ before immunoreaction to enhance antibody penetration and were then processed for immunofluores-

Yoshimura and Nishi, 1992). The four AMPAr subunits (GluR1GluR4/GluRA-GluRD) are differentially expressed in dorsal horn (Nagy et al., 2004; Polgár et al., 2008), with GluR4containing synapses being relatively scarce in superficial laminas but present at high density on certain large lamina I cells. Based on their size, we suggested that these may be projection neurons (Polgár et al., 2008).

The aims of this study were (1) to identify excitatory inputs to the large gephyrin-coated lamina I neurons, (2) to test the hypothesis that they have a high density of GluR4-containing glutamatergic synapses, and (3) to compare their responses to noxious heat with those of multipolar NK1r-expressing neurons. In addition, we estimated the number of these cells in a midlumbar segment and investigated whether they belong to the spinothalamic tract, an important route through which nociceptive information is transmitted to the cerebral cortex. Our results suggest that there are at least two populations of multipolar projection neurons in lamina I that differ not only in NK1r expression but also in excitatory inputs and responses to noxious stimulation.

\section{Materials and Methods}

Animals. Experiments were approved by the Ethical Review Process Applications Panel of the University of Glasgow and the Animal Ethics Committee of the Faculty of Medicine and Health Sciences of the United Arab Emirates University and were performed in accordance with the United Kingdom Animals (Scientific Procedures) Act 1986.

Thirty-five adult male Wistar rats (220-320 g; Harlan or United Arab Emirates University) were used in this study. Twenty-one of these were deeply anesthetized with pentobarbitone and perfused through the left ventricle with a fixative consisting of $4 \%$ freshly depolymerized formaldehyde. Four animals were anesthetized with a mixture of ketamine and xylazine (76 and $19 \mathrm{mg} / \mathrm{kg}$, i.p., respectively, supplemented as necessary) and received injections of $2 \mu \mathrm{l}$ of $1 \%$ cholera toxin B subunit (CTb) (Sigma) into each sciatic nerve. After a $3 \mathrm{~d}$ survival period, these animals were reanesthetized with pentobarbitone and perfused with fixative as described above. Five rats were anesthetized with urethane $(1.7-2.2 \mathrm{~g} / \mathrm{kg}$, i.p.) and had the left hindpaw immersed in water at $52^{\circ} \mathrm{C}$ for $45 \mathrm{~s}$. They were maintained under anesthetic for $2 \mathrm{~h}$ and then perfused with fixative as described above. The remaining five rats were anesthetized with ketamine and xylazine (as above) or with isofluorane and received stereotaxic injections of $200 \mathrm{nl}$ of $4 \%$ Fluorogold targeted on the posterior triangular nucleus of the thalamus (PoT) (Gauriau and Bernard, 2004) on the left side. Injections were made into PoT because we have shown that virtually all lamina I spinothalamic neurons in the lumbar enlargement of the rat can be retrogradely labeled from this region (Al-Khater et al., 2008). Three of these rats also received $200 \mathrm{nl}$ of $1 \% \mathrm{CTb}$ targeted on the left lateral parabrachial area $(\mathrm{LPb})$, because most of the large gephyrin-coated lamina I neurons belong to the spinoparabrachial tract cence staining according to one of the protocols described below. In those experiments in which antibodies against the GluR4 and/or GluR3 subunits were used, antigen retrieval with pepsin was performed before immunostaining to expose these subunits at glutamatergic synapses (Watanabe et al., 1998). The antigen retrieval was performed as described previously (Nagy et al., 2004; Polgár et al., 2008), except that, in some cases, the concentration of pepsin was reduced from 1 to $0.5 \mathrm{mg} / \mathrm{ml}$. Tyramide signal amplification (TSA) was used in some reactions, either because two of the primary antibodies were raised in the same species or to stabilize one type of immunoreaction before antigen retrieval with pepsin (Nagy et al., 2004). The amplification was performed with a TSA kit (tetramethylrhodamine; PerkinElmer Life Sciences) according to the instructions of the manufacturer. Details of the primary antibodies used, their sources, and concentrations are given in Table 1. Species-specific secondary antibodies were raised in donkey and conjugated to Rhodamine Red, cyanine 5.18 (Cy5) (1:100; both from Jackson ImmunoResearch) or Alexa 488 (1:500; Invitrogen). Incubations in primary antibodies were for 1-3 d, whereas those in secondary antibodies were for $1 \mathrm{~d}$. Antibodies were diluted in PBS containing 0.3\% Triton X-100. On completion of the reactions, sections were mounted in anti-fade medium (Vectashield; Vector Laboratories) and stored at $-20^{\circ} \mathrm{C}$.

Sections from unoperated animals were reacted according to one of the following protocols: (1) incubation in mouse monoclonal antibody $(\mathrm{mAb})$ against gephyrin (mAb 7a), which was detected with TSA, followed by incubation in mouse monoclonal anti-neurofilament 200 (NF200) combined with rabbit anti-NK1r, rabbit antibody against vesicular glutamate transporter 2 (VGLUT2), or guinea pig antibody against calcitonin gene-related peptide (CGRP) and then secondary antibodies conjugated to Alexa 488 and Cy5; (2) incubation in rabbit anti-NK1r, guinea pig anti-VGLUT2, and sheep anti-CGRP, followed by secondary antibodies conjugated to Alexa 488, Rhodamine Red, and Cy5; (3) incubation in $\mathrm{mAb} 7 \mathrm{a}$, which was detected with TSA, followed by pepsin treatment and incubation in goat anti-GluR3 and rabbit anti-GluR4 and then in Alexa 488- and Cy5-conjugated secondary antibodies; (4) pepsin treatment followed by incubation in $\mathrm{mAb} 7 \mathrm{a}$, goat anti-GluR3, and rabbit anti-GluR4 and then in Alexa 488-, Rhodamine Red-, and Cy5conjugated secondary antibodies; or (5) incubation in guinea pig antiVGLUT2, which was detected with TSA, and then pepsin treatment and incubation in $\mathrm{mAb} 7 \mathrm{a}$ and rabbit anti-GluR4, followed by Alexa 488- and Cy5-conjugated secondary antibodies. All of these immunostaining protocols were performed on horizontal sections, and, in addition, transverse sections were reacted according the first protocol (the combination with rabbit anti-NK1r). Horizontal sections from the rats that received $\mathrm{CTb}$ injections into the sciatic nerves were reacted with $\mathrm{mAb} 7 \mathrm{a}$ (detected with TSA) and then with mouse anti-NF200 and goat anti-CTb (detected with secondary antibodies conjugated to Alexa 488 and Cy5). Horizontal sections from rats that received the noxious heat stimulus were reacted with $\mathrm{mAb} 7 \mathrm{a}$, rabbit antibody against Fos, and guinea pig anti-NK1r, which were revealed with secondary antibodies conjugated to Alexa 488, 
Rhodamine Red, and Cy5. Spinal cord sections from rats that had received stereotaxic brain injections were incubated in $\mathrm{mAb} 7 \mathrm{a}$, guinea pig antibody against Fluorogold, and, for those that received $\mathrm{CTb}$ injection, goat antibody against $\mathrm{CTb}$. They were then placed in secondary antibodies conjugated to Alexa 488, Rhodamine Red, and Cy5. CTb injection sites in these animals were revealed with an immunoperoxidase method (Al-Khater et al., 2008), whereas the Fluorogold sites were viewed with an epifluorescence microscope.

The monoclonal antibody N52 recognizes both phosphorylated and nonphosphorylated forms of neurofilaments with a molecular weight of $200 \mathrm{kDa}$, and the two CGRP antibodies detect both $\alpha$ and $\beta$ forms of the peptide. The rabbit NK1r antibody was raised against a peptide corresponding to amino acids 393-407 of the rat receptor conjugated to keyhole limpet hemocyanin, and staining with this antibody is absent in the brains of NK1r knock-out mice (Ptak et al., 2002). Staining with the guinea pig NK1r antibody is abolished by pretreatment with the immunizing peptide (Polgár et al., 1999). The affinity-purified GluR4 antibodies were both raised against a peptide corresponding to the C-terminal region of the subunit, and both recognize bands of $\sim 105 \mathrm{kDa}$ in Western blots of rat brain extracts (the specifications of the manufacturers). The GluR3 antibody was raised against glutathione $S$-transferase (GST) fused to residues $830-862$ of the mouse GluR3 subunit and staining with this antibody is absent in spinal cords from GluR3 knock-out mice (Polgár et al., 2008). The rabbit antiVGLUT2 was raised against a GST fusion protein containing amino acids $510-582$ of rat VGLUT2 and recognizes a single protein band of $\sim 65 \mathrm{kDa}$ in rat brain membrane fractions. The guinea pig VGLUT2 antibody was raised against a peptide from rat VGLUT2, and we have shown that it stains identical structures to the rabbit VGLUT2 antibody in sections of rat spinal cord (Todd et al., 2003). The Fos antibody recognizes a band of $\sim 62 \mathrm{kDa}$ in A-431 cells stimulated with phorbol-ester or epidermal growth factor (the specification of the manufacturer).

Confocal microscopy and analysis. All sections were scanned with a Radiance 2100 confocal microscope (Bio-Rad). Sequential scanning was used to minimize fluorescent bleed through. All of the analysis was performed on confocal image stacks obtained with a $40 \times$ or $60 \times$ oil-immersion lens, apart from the counts of the gephyrin-coated neurons and the investigation of Fos expression, which were performed with a $20 \times$ objective lens.

We have shown previously that certain large dorsal horn neurons contain NF200 (Polgár et al., 2007), and, during the course of this study, we found that the large gephyrin-coated lamina I neurons were invariably NF200 positive. The NF200 immunoreactivity revealed the dendritic morphology of these cells and allowed the identification of contacts from different neurochemical types of axonal boutons onto all parts of their dendritic trees. This was necessary because, although gephyrin puncta coat the cell bodies and proximal dendrites of these neurons, they do not reliably outline distal dendrites. In addition, glutamatergic boutons are not directly apposed to the gephyrin puncta,
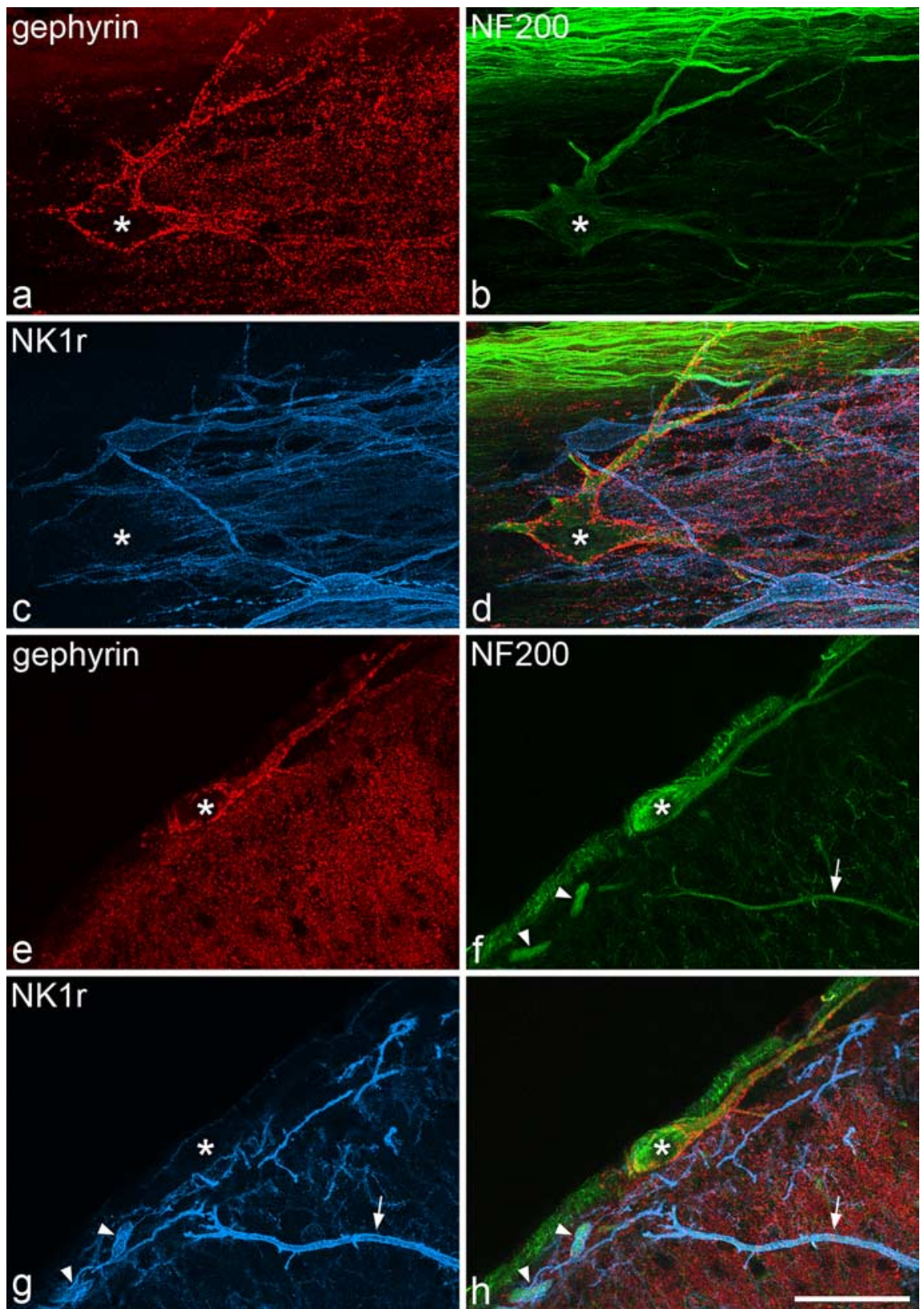

Figure 1. Immunostaining for gephyrin, NF200, and the NK1 receptor in horizontal and transverse sections. $\boldsymbol{a}-\boldsymbol{d}$, Confocal images through part of a large lamina I cell (asterisk) in a horizontal section, scanned to reveal gephyrin (red), NF200 (green), and NK1r (blue), together with a merged image. The soma and dendrites of this neuron are coated with gephyrin puncta but are not NK1r immunoreactive. The cell contains NF200 immunoreactivity, which is relatively weak in the cell body and strong in the dendrites. Numerous axons with strong NF200 immunoreactivity are seen in the white matter in the upper part of the field. $\boldsymbol{e}-\boldsymbol{h}$, Confocal images scanned through a large lamina I cell (asterisk) in a transverse section. Again, the cell body and dendrites are NF200 positive, NK1r negative and have numerous gephyrin puncta on them. Two NK1r-immunoreactive dendrites that also contain NF200 (arrowheads), belong to a lamina I neuron, although the soma of this cell is not present in this field. The arrow shows the dendrite of a neuron from the deeper part of the dorsal horn that is immunoreactive for both NK1r and NF200. Images are made from projections of $26(\boldsymbol{a}-\boldsymbol{d})$ or $18(\boldsymbol{e}-\boldsymbol{h})$ optical sections at $1 \mu \mathrm{m} z$-spacing. Scale bar, $50 \mu \mathrm{m}$.

and the NF200 revealed the surfaces of cell bodies and dendrites between these puncta.

To examine the morphology of these cells, horizontal sections from four unoperated rats that had been reacted with antibodies against gephyrin, NF200, and NK1r were examined, and 15 cells were selected (two to five cells per rat). These were scanned through a $40 \times$ lens to produce $z$-series at $1 \mu \mathrm{m} z$-separation. The tissue was scanned so as to include as much of the dendritic tree as could be followed, and, in some cases, dendrites from a single cell were scanned in more than one Vi- 
bratome section. Dendritic trees of these cells were drawn with Neurolucida for Confocal software (MicroBrightField).

Because the most lateral part of lamina I is difficult to identify in horizontal sections, counts of the gephyrin-coated lamina I cells were performed by examining uninterrupted series of between 36 and 4860 $\mu \mathrm{m}$-thick transverse sections from the L4 segment of three rats. These sections had been reacted with antibodies against gephyrin, NF200, and NK1r and were mounted in serial order. Care was taken to ensure that cells with somata at the cut surfaces of the Vibratome sections were not double counted. The mean number of cells per side in each series was divided by the length of the spinal cord analyzed (estimated from the number of sections in the series) and expressed per $2.5 \mathrm{~mm}$ (the average length of the L4 segment) (Polgár et al., 2004).

All of the remaining analysis was performed on horizontal sections. To investigate the density of contacts that the gephyrin-coated cells received from different types of glutamatergic axon, we examined sections from unoperated rats that had been reacted with $\mathrm{mAb} 7 \mathrm{a}$ and anti-NF200, together with either VGLUT2 or CGRP antibodies. CGRP is a marker for peptidergic primary afferent terminals (Ju et al., 1987), whereas VGLUT2 is expressed by most (if not all) excitatory interneurons in the superficial dorsal horn, as well as by A $\delta$ nociceptors (Oliveira et al., 2003; Todd et al., 2003; Alvarez et al., 2004; Cheng et al., 2004; Maxwell et al., 2007; Schneider and Walker, 2007). The density of contacts from VGLUT2- and CGRP-immunoreactive boutons was determined for 12 of the large gephyrin-coated lamina I neurons (four cells from each of three rats for each axonal marker). The cells (and the regions of dendritic tree to be analyzed; see below) were selected before visualizing the VGLUT2 or CGRP immunoreactivity to avoid the possibility of bias. They were initially scanned through the $40 \times$ lens to reveal gephyrin and NF200, and the resulting confocal image stacks were used to reconstruct their dendritic trees with Neurolucida. Selected regions of the dendritic tree were then scanned for all three types of immunoreactivity through the $60 \times$ lens with a $z$-separation of $0.5 \mu \mathrm{m}$. These regions were viewed with Neurolucida, and the positions of contacts from immunoreactive boutons were plotted. Surface areas of these regions of dendrite were estimated from their diameters and lengths, based on the assumption that the dendrites were cylindrical, and the density of contacts per $1000 \mu \mathrm{m}^{2}$ of dendritic surface area was then calculated. To determine whether there was a difference in contact density between proximal and distal dendrites, these were analyzed separately, with regions of dendritic tree located $<150 \mu \mathrm{m}$ from the soma being classed as proximal and the remainder as distal. For each cell, at least $100 \mu \mathrm{m}$ of both proximal and distal dendrites was analyzed. A similar method was used to analyze the density of contacts between VGLUT2-immunoreactive boutons and the dendrites of large multipolar NK1r-immunoreactive lamina I cells (12 cells, four each from three rats). Again, the selection of cells and regions of dendritic tree to be analyzed was made before the VGLUT2 immunoreactivity was viewed. To determine whether the large gephyrin-coated cells received significant input from A $\delta$ primary afferent axons in lamina I that were transganglionically labeled with $\mathrm{CTb}, 16$ of these neurons (two to five cells from each of the four rats that had received sciatic nerve injections) were selected from areas in which there were numerous CTblabeled boutons in lamina I. Sections were scanned and analyzed as described above, although no distinction was made between proximal and distal dendrites for this part of the study, because the density of contacts was found to be very low in most cases. All of the analyses of contacts were performed on optical sections through regions of the tissue in which there was good penetration of immunostaining.

The expression of synaptic AMPAr subunits was examined in sections that had been processed for antigen retrieval with pepsin. Fourteen cells from four unoperated rats (three to five from each rat) were selected from sections reacted with antibodies against gephyrin, GluR3, and GluR4 (protocols 3 and 4, above). Because synaptic labeling with AMPAr subunit antibodies is generally limited to the superficial regions within Vibratome sections (Nagy et al., 2004), cells were only examined if parts of their dendritic trees were close to the section surface, and only these regions were scanned and analyzed. To determine whether synapses were present at the contacts between VGLUT2-immunoreactive boutons and dendrites of the large gephyrin-coated cells, we looked for punctate

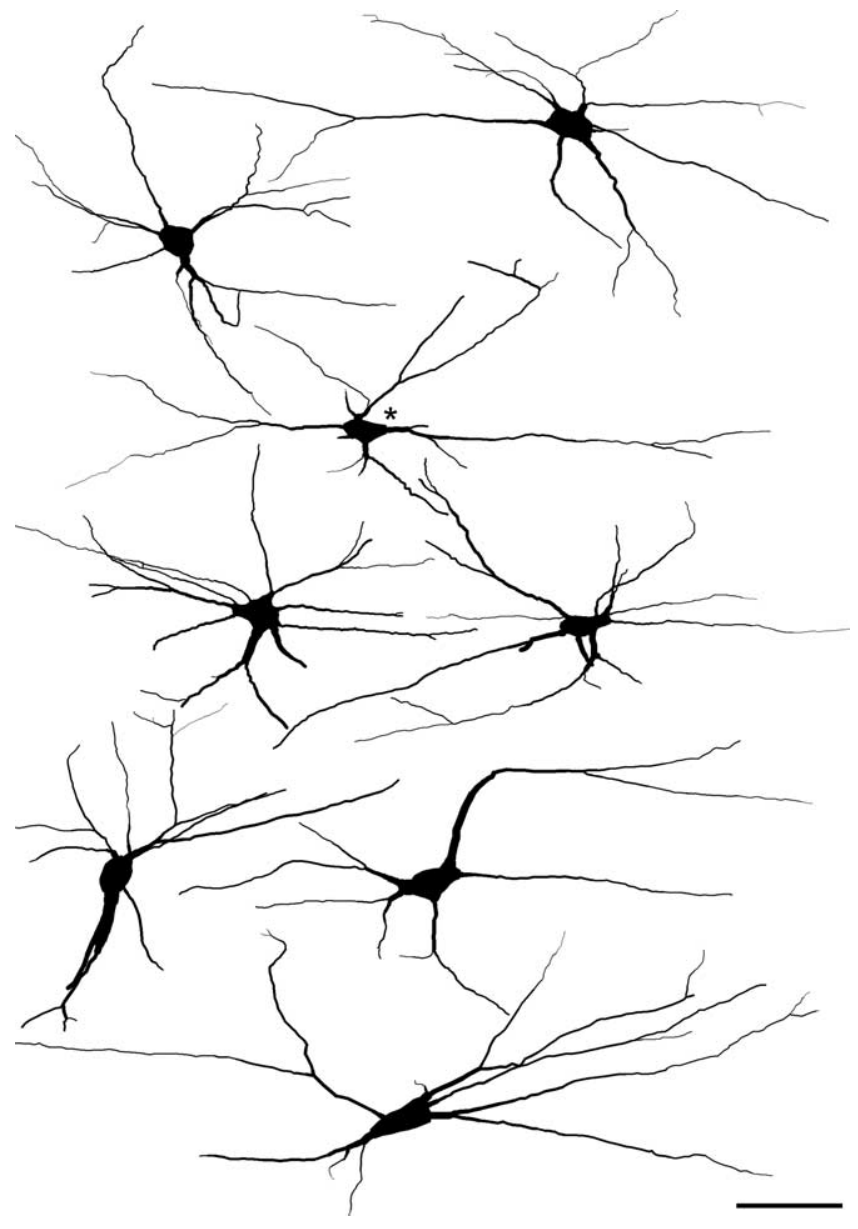

Figure 2. Drawings of 8 of the 15 large gephyrin-coated neurons for which dendritic morphology was analyzed. All of the cells were viewed in horizontal sections through lamina I that had been reacted with antibodies against gephyrin, NF200, and NK1r, and, in some cases, they were reconstructed from confocal images from more than one Vibratome section. The cells were drawn with Neurolucida for Confocal software based on their NF200 immunoreactivity. In each case, the rostrocaudal axis is horizontal and the mediolateral axis is vertical. The cell marked with the asterisk is the one that appears in Figure $1 a-d$. Scale bar, $100 \mu \mathrm{m}$.

GluR4 staining at these contacts. Four cells (two each from two rats) were selected from sections reacted with antibodies against VGLUT2, gephyrin, and GluR4 (protocol 5). Again, regions of dendrite near the section surface were scanned with the confocal microscope.

Expression of Fos was investigated on the ipsilateral (left) side of the L5 segment from the five rats that been stimulated with hot water. Initially, the region of lamina I that contained Fos-positive nuclei was determined, and then all of the large gephyrin-coated cells that were present within this region were identified and scanned to reveal gephyrin, NK1r, and Fos immunoreactivity. For comparison, multipolar NK1r-immunoreactive lamina I cells in these scans were also examined. The presence or absence of Fos immunoreactivity in the nuclei of the selected cells was determined.

Horizontal sections from the L5 segments of the rats that had received stereotaxic tracer injections were scanned, and large gephyrin-coated lamina I cells on the contralateral (right) side were identified. The proportion of these cells that were retrogradely labeled with Fluorogold and/or CTb was then determined, as well as the total number of lamina I neurons that were retrogradely labeled from the contralateral thalamus.

\section{Results}

\section{NF200 expression and morphology of large gephyrin-coated} lamina I neurons

Cells that belonged to this population were identified in horizontal sections immunostained for gephyrin, NK1r, and NF200 by 
the high density of gephyrinimmunoreactive puncta that surrounded their cell bodies and proximal dendrites (Fig. $1 a-d$ ). As described previously (Puskár et al., 2001), these cells were either unstained or very weakly stained with the NK1r antibody. All of these cells showed NF200 immunoreactivity, which was sometimes faint in the cell body (Fig. 1b,d) but was strong in the dendrites, and this allowed the dendritic morphology of these cells to be examined in more detail than was possible previously. All of the 15 selected cells were multipolar, with between four and nine primary dendrites, and examples are illustrated in Figure 2. The dendrites generally remained in lamina I or the overlying white matter without penetrating ventrally into deeper laminas. Dendritic trees could be followed for $540 \pm$ $131 \mu \mathrm{m}$ (mean $\pm \mathrm{SD}$ ) in the rostrocaudal axis and $272 \pm 51 \mu \mathrm{m}$ in the mediolateral axis, with the maximum length of dendrite (measured from the soma) varying from 247 to $430 \mu \mathrm{m}$.

These cells were readily identified in transverse sections by the presence of NF200 and the numerous gephyrin puncta on their cell bodies and primary dendrites (Fig. $1 e-h$ ). Cell bodies of these neurons were seen throughout the mediolateral extent of lamina I and were generally located in its most superficial part or within the dorsal columns just above the medial half of the lamina. Between 8 and 12 cells of this type were seen on either side in each of the series of sections through the L4 segments from the three rats analyzed in this part of the study, and this corresponded to a mean value of 10.5 cells (range of 9.6-11.4) on each side per $2.5 \mathrm{~mm}$ length of spinal cord. In both horizontal and transverse sections, NF200 immunoreactivity was also observed in the cell bodies and dendrites of some of the larger NK1r-positive lamina I cells, as well as in axons in the dorsal columns, whereas in transverse sections, it was seen in the dorsal dendrites of cells in deeper laminas, some of which were NK1r immunoreactive (Fig. $1 e-h$ ), as we reported previously (Polgár et al., 2007).

\section{Contacts between glutamatergic axons and lamina I neurons}

All of the large gephyrin-coated lamina I neurons were found to receive numerous contacts from boutons with strong VGLUT2 immunoreactivity. These con-

tacts were invariably present on cell bodies and on both proximal and distal dendrites (Fig. $3 a-h$ ). The contacts from VGLUT2immunoreactive boutons, which were located between the gephyrin puncta, were so numerous that they outlined the cell bodies and much of the dendritic trees of these cells. The mean bars, $10 \mu \mathrm{m}$.
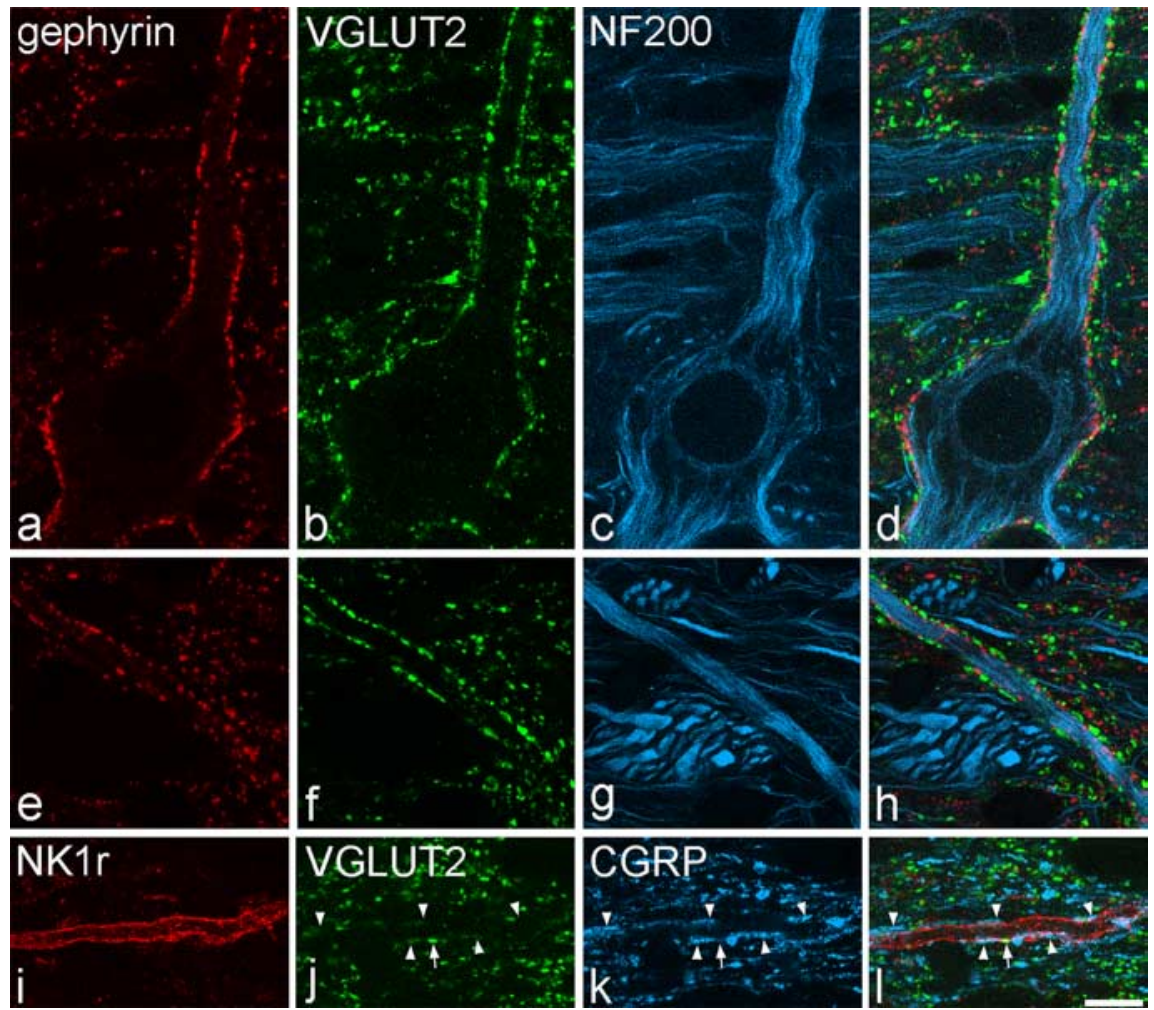

Figure 3. Contacts between VGLUT2-immunoreactive axons and lamina I cells in horizontal sections. $\boldsymbol{a}-\boldsymbol{d}$ show confocal images scanned to reveal gephyrin (red), VGLUT2 (green), and NF200 (blue) through the cell body and a proximal dendrite of a large lamina I neuron. The cell, which contains NF200, is coated with gephyrin puncta and receives numerous contacts from boutons with strong VGLUT2 immunoreactivity. $\boldsymbol{e}-\boldsymbol{h}$ show part of a dendrite belonging to this cell that is located $>150 \mu \mathrm{m}$ from the soma, scanned to reveal the same types of immunoreactivity. Again, the dendrite has numerous gephyrin puncta and is outlined by numerous contacts from VGLUT2-positive boutons. i-I, Confocal scans (NK1r, red; VGLUT2, green; CGRP, blue) through a distal dendrite belonging to an NK1r-positive lamina I cell. The dendrite receives a single contact from a bouton with strong VGLUT2 immunoreactivity (arrow) and several contacts from CGRP-immunoreactive boutons (arrowheads), some of which show weak VGLUT2 labeling. Images are projections from two $(\boldsymbol{a}-\boldsymbol{d})$ or three $(\boldsymbol{e}-\boldsymbol{h}, \boldsymbol{i}-\boldsymbol{I})$ optical sections at $0.5 \mu \mathrm{m} z$-separation. Scale
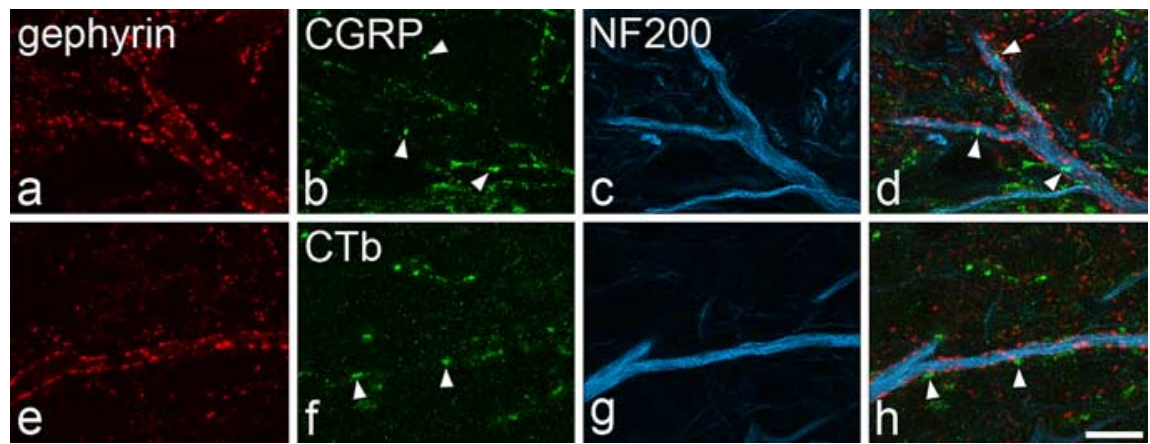

Figure 4. Contacts between CGRP-containing or CTb-labeled primary afferents and dendrites of large gephyrin-coated lamina I cells in horizontal sections. $a-d$, Confocal images scanned to reveal gephyrin (red), CGRP (green), and NF200 (blue) show part of a dendrite that is coated with gephyrin, contains NF200, and receives a few contacts from CGRP-immunoreactive boutons ( 3 of which are labeled with arrowheads). $\boldsymbol{e}-\boldsymbol{h}$ were scanned to reveal gephyrin (red), CTb (green), and NF200 (blue) from a rat in which CTb had been injected into the sciatic nerve $3 \mathrm{~d}$ previously. Part of a dendrite that contains NF200 and is coated with gephyrin puncta is shown, and this receives contacts from CTb-labeled varicosities ( 2 shown with arrowheads). All images are projections from four optical sections at $0.5 \mu \mathrm{m} z$-separation. Scale bar, $10 \mu \mathrm{m}$.

densities of VGLUT2 contacts per $1000 \mu \mathrm{m}^{2}$ on the proximal and distal dendrites of these cells were $115 \pm 21$ (mean \pm SD) and $163 \pm 72$, respectively. The NK1r-expressing lamina I cells also received contacts from VGLUT2-immunoreactive boutons $\left(26 \pm 7\right.$ and $37 \pm 14$ contacts per $1000 \mu \mathrm{m}^{2}$ for proximal and 


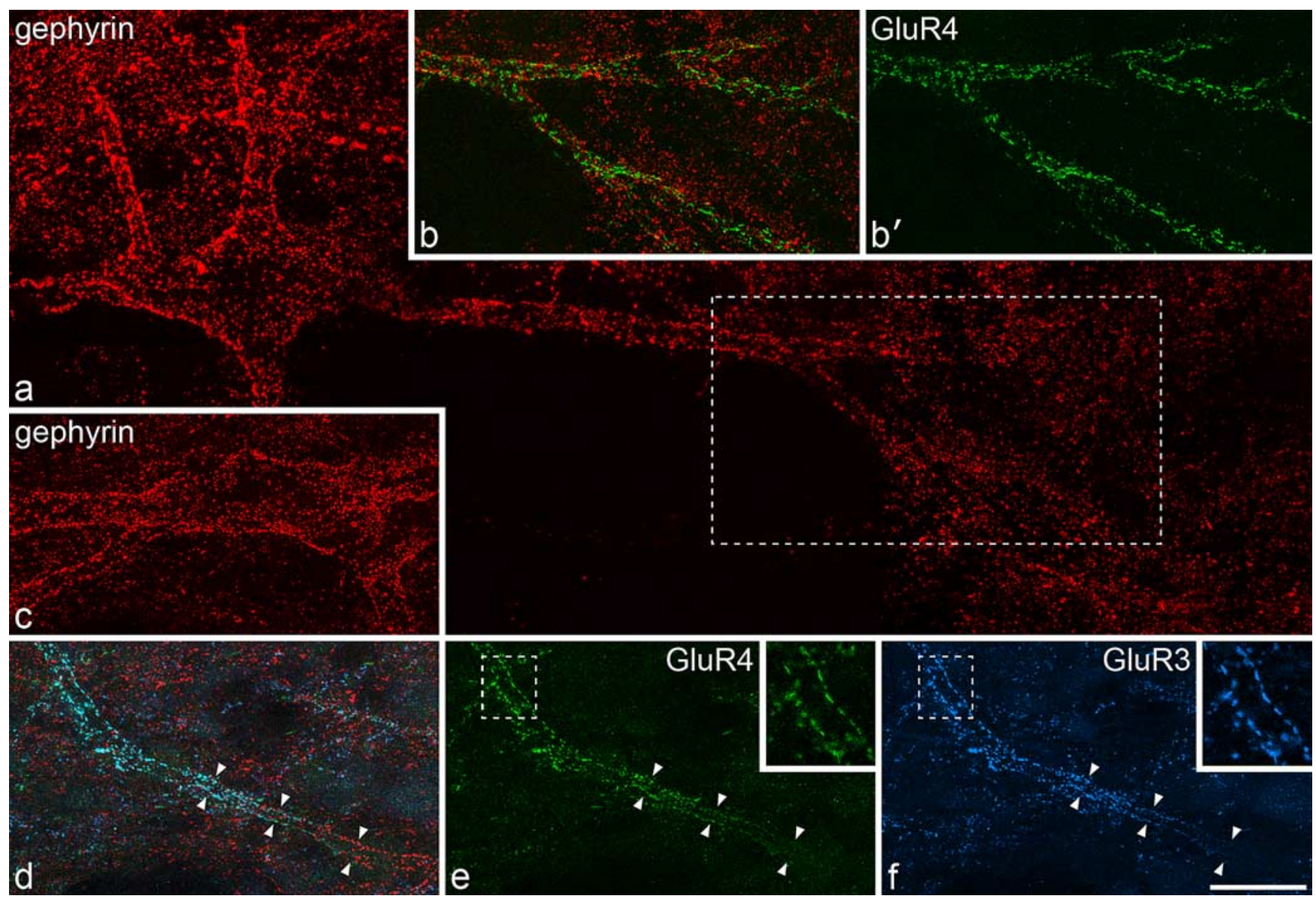

Figure 5. AMPAr subunit expression on large lamina I gephyrin-coated cells in horizontal sections. All images are from horizontal sections that had undergone antigen retrieval with pepsin. a shows a large lamina I neuron scanned for gephyrin (red). The gephyrin puncta on this cell outline the soma and dendrites. The region in the box includes part of the dendritic tree of this cell and is shown in $\boldsymbol{b}$ and $\boldsymbol{b}^{\prime}$. These images have been scanned to reveal both gephyrin and GluR4 (green) (b) and GluR4 alone $\left(\boldsymbol{b}^{\prime}\right)$. This part of the dendritic tree is also outlined by numerous GluR4immunoreactive puncta. c shows the cell body of another gephyrin-coated neuron. $\boldsymbol{d}-\boldsymbol{f}$, A dendrite (marked by arrowheads) that belongs to the cell shown in $\boldsymbol{c}$. The part of this dendrite to the right of the field was relatively deep within the section and has numerous gephyrin puncta. The region of dendrite to the left of the field approached the section surface and shows large numbers of GluR3 (blue) and GluR4 (green) puncta. The areas in the boxes in $\boldsymbol{e}$ and $\boldsymbol{f}$ are shown at higher magnification in the insets. Note the alignment of GluR3 and GluR4 puncta on either side of the dendritic shaft. $\boldsymbol{a}$ was obtained from five confocal image stacks each consisting of between 20 and 41 optical sections at $0.5 \mu \mathrm{m} z$-spacing; $\boldsymbol{b}$ and $\boldsymbol{b}^{\prime}$ were from two image stacks ( 30 and 36 optical sections at 0.5 $\mu \mathrm{m} z$-spacing); $\boldsymbol{c}$ was from two image stacks ( 28 and 32 optical sections at $0.5 \mu \mathrm{m} z$-spacing); $\boldsymbol{d}$-f are projections of 22 optical sections at $0.5 \mu \mathrm{m} z$-spacing and the insets are from single optical sections. Scale bar, $20 \mu \mathrm{m}$.

distal dendrites, respectively). Two-way ANOVA with post hoc all pairwise multiple comparisons (Holm-Sidak method) revealed that the large gephyrin-coated cells received significantly more contacts from VGLUT2 axons per $1000 \mu \mathrm{m}^{2}$ than the NK1rimmunoreactive neurons $(p<0.001)$ and that the gephyrincoated cells had a significantly higher density of contacts on distal than on proximal dendrites $(p<0.01)$. The sections that were used to analyze VGLUT2 contacts on the NK1r cells had also been immunostained for CGRP, and we found that, although some of the boutons that contacted these cells showed strong VGLUT2 immunoreactivity and lacked CGRP, many of them were weakly labeled for the transporter and were also CGRP immunoreactive (Fig. $3 i-l$ ). This is consistent with previous reports that only weak VGLUT2 immunoreactivity is observed in CGRP-containing boutons in the superficial dorsal horn (Todd et al., 2003; Alvarez et al., 2004).

The gephyrin-coated lamina I neurons also received contacts from CGRP-immunoreactive boutons, but these were at a very low density $\left(3 \pm 2\right.$ and $7 \pm 3$ contacts per $1000 \mu \mathrm{m}^{2}$ for proximal and distal dendrites, respectively) and were never arranged in such a way as to outline parts of the dendritic trees of the cells
(Fig. $4 a-d$ ), as occurs with CGRP contacts on the dendrites of NK1r-immunoreactive lamina I neurons (Fig. 3i-l) (Todd et al., 2002, their Fig. 5).

In the sections from rats that had received injections of $\mathrm{CTb}$ into the sciatic nerve, CTb-immunoreactive boutons were observed in lamina I on both sides. Fourteen of the 16 gephyrincoated cells that were analyzed in these sections received very few contacts from CTb-immunoreactive boutons $(<2$ contacts per $1000 \mu \mathrm{m}^{2}$ ), whereas the remaining two cells had a moderate density of contacts ( 8 and 12 contacts per $1000 \mu \mathrm{m}^{2}$ ) (Fig. $4 e-h$ ).

\section{AMPAr expression by gephyrin-coated cells}

In sections processed for antigen retrieval to reveal synaptic AMPAr subunits, both GluR3 and GluR4 antibodies gave a punctate pattern of immunolabeling, as described previously (Nagy et al., 2004; Polgár et al., 2008). Penetration of GluR3 staining was generally limited to regions within $\sim 5 \mu \mathrm{m}$ of the section surface, although punctate GluR4 staining was often seen in deeper parts of the sections. Dendrites of the large gephyrin-coated cells were seen to be associated with clusters of GluR4 puncta that also outlined them and were interspersed between the gephyrin 
puncta (Fig. 5a,b). In all cases examined, those dendrites that lay close to the section surface were outlined by puncta that were immunostained for both GluR3 and GluR4 (Fig. $5 c-f$ ), and at least 30 such puncta were identified on each of the 14 cells analyzed. In some cases, particularly when TSA was not used to reveal gephyrin, the gephyrin staining became weaker near the section surface. However, it was still possible to find regions of dendrite that had both gephyrin and GluR3/GluR4 puncta (Fig. $5 d-f$ ).

In sections that had been reacted with antibodies against VGLUT2, gephyrin, and GluR4, numerous VGLUT2immunoreactive boutons were apposed to dendrites that belonged to large gephyrin-coated lamina I cells. On the parts of these dendrites that lay close to the section surface, large numbers of GluR4 puncta were found between the gephyrin puncta, and both of these types of immunoreactivity outlined the dendritic shafts. Many of the VGLUT2-immunoreactive boutons that were adjacent to these dendrites were directly apposed to GluR4 puncta on the dendrites of these cells (Fig. 6), and at least 100 such appositions were observed for each of the four cells examined.

\section{Fos in response to noxious heat}

In the rats that had received noxious heat stimulation, large numbers of Fos-positive nuclei were detected in the superficial dorsal horn on the ipsilateral side. Between five and seven of the large gephyrin-coated neurons and between 10 and 14 multipolar NK1r-immunoreactive cells were identified within the area of Fos expression in lamina I from each of these five rats. The proportions of these cells that had Fos-positive nuclei varied from 29 to $57 \%$ (mean of $38 \%$ ) for the gephyrin-coated neurons and from 80 to $90 \%$ (mean of $85 \%$ ) for the NK1r cells, and examples of labeling are shown in Figure 7. Analysis of the pooled data showed that this difference was highly significant $(p<0.001, z$ test). We also observed that, although some of the NK1r cells had nuclei that were strongly labeled for Fos (Fig. $7 b-d$ ), only weak or moderate labeling was present in the nuclei of the gephyrincoated cells (Fig. $7 e-g$ ).

\section{Thalamic projection of large gephyrin-coated lamina I cells}

In all five stereotaxic injection experiments, the PoT was completely filled with Fluorogold, which also spread into surrounding regions of the thalamus as well as into adjacent areas such as the anterior pretectal and deep mesencephalic nuclei (Fig. $8 f, g$ ). However, there was no spread of Fluorogold into the hypothalamus, periaqueductal gray matter, or parabrachial area. In the three rats that also received $\mathrm{CTb}$ injections, the tracer filled the $\mathrm{LPb}$ with some spread into the medial parabrachial, cuneiform, and Kolliker-Fuse nuclei (Fig. 8e). In one case, there was also slight spread of $\mathrm{CTb}$ into the periaqueductal gray matter.

In these five experiments, between 6 and 12 (mean of 8.4) large gephyrin-coated lamina I cells were identified on the right side of the L5 segment, and between one and five (mean of 3.2) of these were retrogradely labeled with Fluorogold (Fig. $8 a, c, d$ ). The total numbers of Fluorogold-labeled lamina I neurons that were identified on the right side in these experiments varied from 13 to 22 (mean of 17.6). In the three experiments in which CTb was injected into the LPb, $86-89 \%$ of the large gephyrin-coated lamina I cells were retrogradely labeled with CTb (Fig. $8 a, b, d)$.

\section{Discussion}

The main findings of this study are (1) that the large gephyrincoated lamina I neurons have a very high density of synaptic input from glutamatergic boutons that contain VGLUT2 but ap-
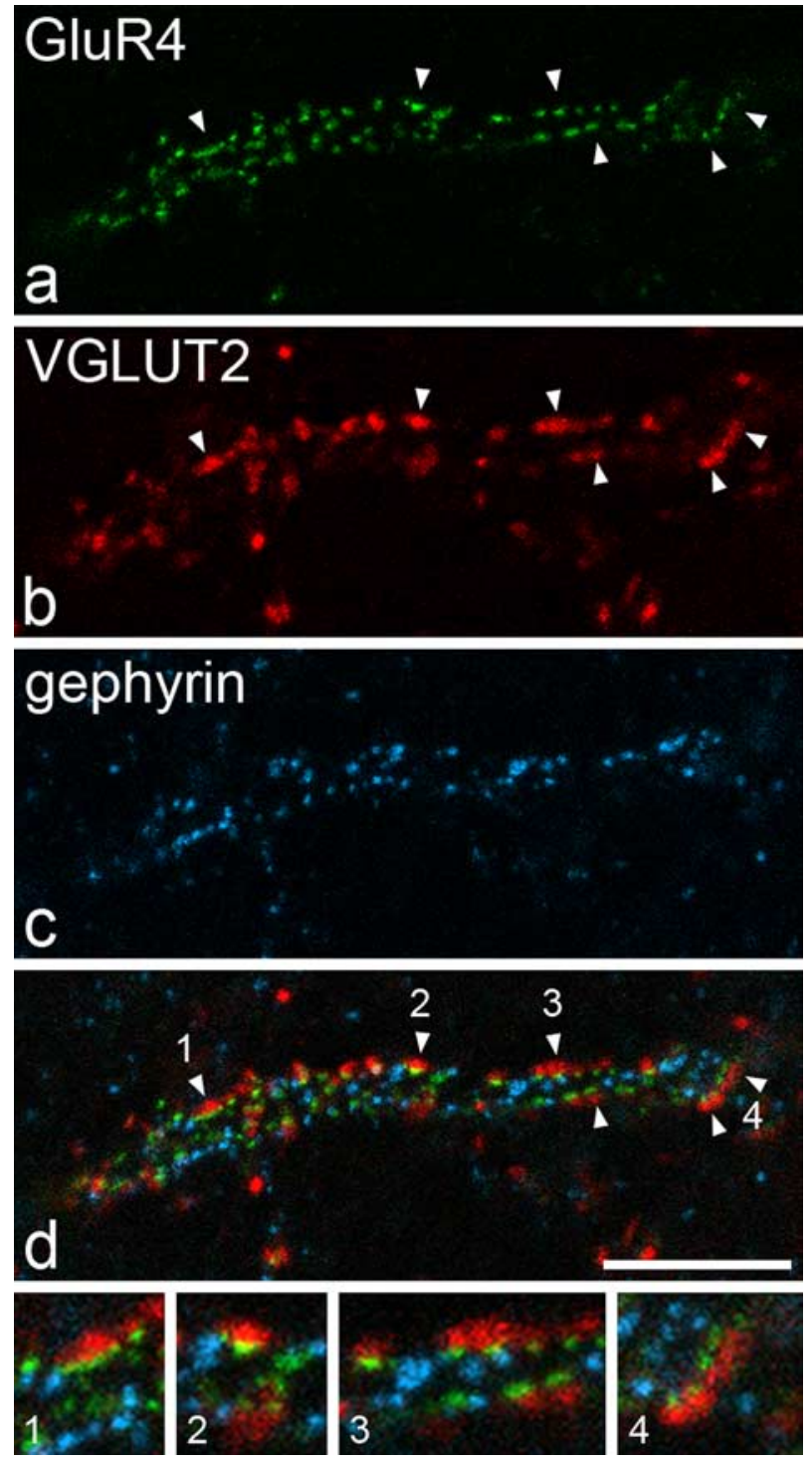

Figure 6. Appositions from VGLUT2-immunoreactive axons are associated with GluR4containing puncta on the dendrites of a gephyrin-coated lamina I neuron. $\boldsymbol{a}$ - $\boldsymbol{c}$ show part of a horizontal section that had been reacted to reveal VGLUT2 with the tyramide signal amplification method, processed for antigen retrieval with pepsin and then incubated in antibodies against gephyrin and GluR4. A stretch of dendrite that belongs to a large gephyrin-coated lamina I neuron is outlined by both GluR4 (green) and gephyrin (blue) puncta and is associated with VGLUT2-immunoreactive boutons (red). The merged image ( $\boldsymbol{d}$ ) shows that several of the VGLUT2 boutons are directly apposed to GluR4 puncta on the dendrite, and some of these are indicated with arrowheads. Some of these appositions are shown at higher magnification in the four images at the bottom of the figure (numbers refer to those in $\boldsymbol{d}$ ). The images are projections of three confocal images at $0.5 \mu \mathrm{m} z$-separation. Scale bar, $10 \mu \mathrm{m}$.

parently receive few contacts from peptidergic or A $\delta$ nociceptive primary afferents, (2) that these cells possess AMPArs that contain both GluR3 and GluR4 at their glutamatergic synapses, (3) that they are significantly less likely than NK1r-expressing multipolar cells in lamina I to upregulate Fos in response to noxious thermal stimulation, and (4) that they constitute $\sim 18 \%$ of the lamina I spinothalamic neurons in the L5 segment.

\section{AMPAr expression by large gephyrin-coated lamina I cells} AMPAr subunits at glutamatergic synapses are not reliably detected with conventional immunocytochemistry, because fixation-induced crosslinking of synaptic proteins prevents ac- 

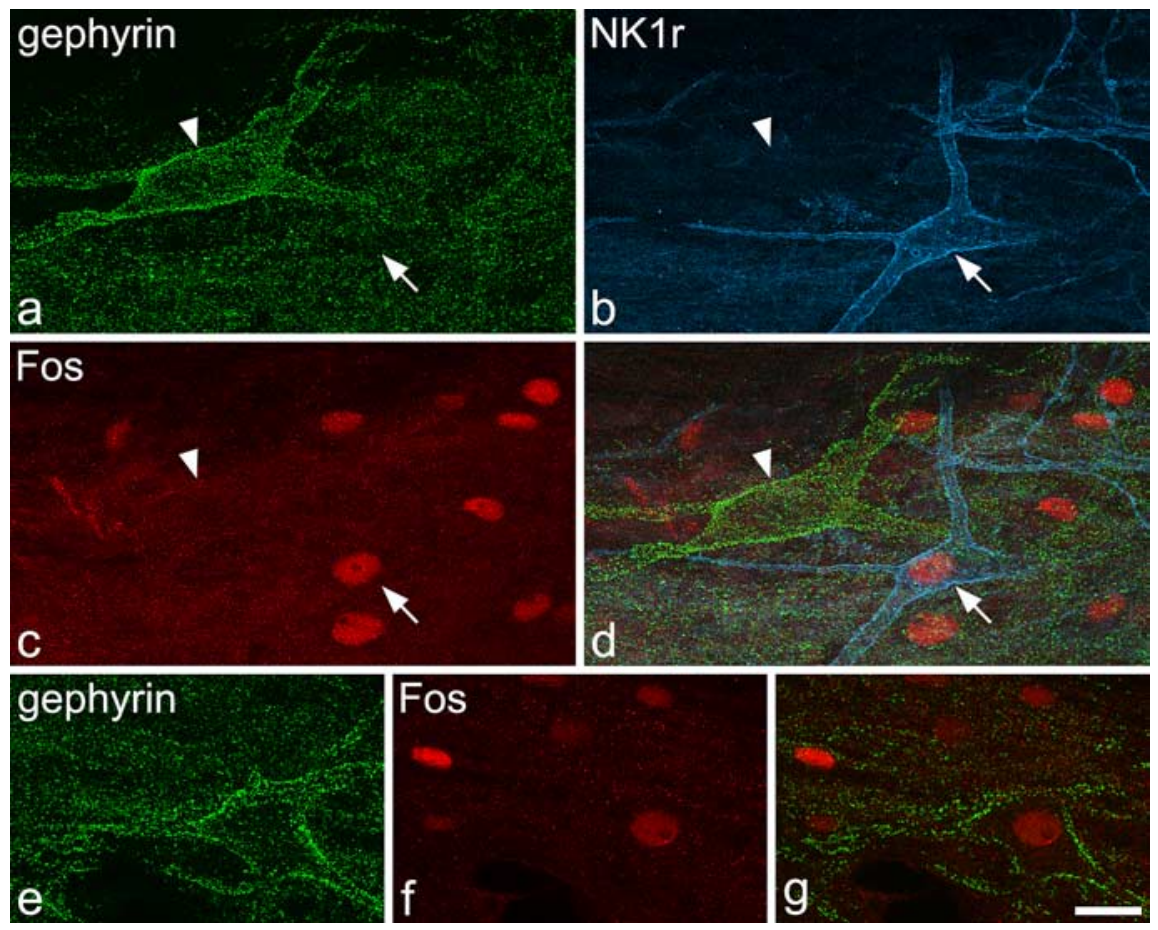

Figure 7. Fos expression seen $2 \mathrm{~h}$ after immersion of one hindpaw in water at $52^{\circ} \mathrm{C}$ for $45 \mathrm{~s} . \boldsymbol{a}$ - $\boldsymbol{d}$ show a field from a horizontal section through lamina I that had been reacted to reveal gephyrin (green), NK1r (blue,) and Fos (red). A large gephyrin-coated cell (arrowhead) and a multipolar NK1r-immunoreactive neuron (arrow) are both visible. Several nuclei (including that of the NK1rimmunoreactive neuron) are labeled with the Fos antibody, but the nucleus of the gephyrin-coated cell is Fos negative. e shows another gephyrin-coated lamina I cell. $\boldsymbol{f}$ and $\boldsymbol{g}$ are scans through this cell that reveal weak Fos staining in its nucleus. Images are projections of $12(\boldsymbol{a}-\boldsymbol{d}), 15(\boldsymbol{e})$, and $4(\boldsymbol{f}, \boldsymbol{g})$ optical sections at $1 \mu \mathrm{m} z$-spacing. Scale bar, $20 \mu \mathrm{m}$. of AMPArs. For example, GluR1 subunits at synapses in superficial dorsal horn can undergo (PKA-dependent) phosphorylation at the $\mathrm{S} 845$ residue after noxious stimulation (Nagy et al., 2004), and there is growing evidence that insertion of GluR1-containing receptors into dorsal horn synapses plays a significant role in inflammatory pain states (Galan et al., 2004; Katano et al., 2008; Larsson and Broman, 2008). GluR4, like GluR1, can undergo PKA-mediated phosphorylation and activity-dependent insertion (Esteban et al., 2003), and it is possible that these mechanisms contribute to central sensitization of the large gephyrin-coated projection neurons.

Although GluR4-containing synapses are relatively uncommon in the superficial laminas, they are not restricted to this population of cells, because we found that they are also present on dorsal dendrites of NK1r-expressing lamina III projection neurons and on some large NK1rimmunoreactive neurons in lamina I (A. J. Todd, unpublished observations). This suggests that GluR4-containing AMPArs may be restricted to projection cells in superficial dorsal horn and indicates that they have a significant role in nociceptive transmission. cess of antibodies. After antigen retrieval with pepsin AMPAr antibodies give punctate staining, and we have provided several lines of evidence to confirm that these puncta correspond to postsynaptic receptors (Nagy et al., 2004; Polgár et al., 2008): (1) staining with antibodies against GluR1-GluR3 is absent in tissue from the corresponding knock-out mice, (2) the puncta are associated with each neurochemical type of glutamatergic axon terminal throughout the spinal cord, (3) punctate AMPAr staining is colocalized with that for postsynaptic density protein PSD-95, and (4) puncta are found to be located at postsynaptic sites with electron microscopy.

In a recent study, we reported that GluR4 was present at $23 \%$ of AMPAr-containing puncta in lamina I and $<10 \%$ of those in lamina II (Polgár et al., 2008). In lamina I, these formed dense clusters that outlined dendritic shafts of certain neurons, and, based on their size, we suggested that these were projection cells. Here we confirm this by showing that at least some of the clusters of GluR4-containing synapses are associated with dendrites of the large gephyrin-coated lamina I projection neurons. Polgár et al. (2008) reported that the GluR4containing puncta in lamina I were also immunoreactive for GluR2 and GluR3. We have shown previously that GluR2 is present at virtually all AMPAr-containing synapses in the spinal cord (Nagy et al., 2004), whereas GluR4 and GluR1 are not colocalized in lamina I (Polgár et al., 2008). This suggests that synaptic AMPArs on the gephyrin-coated lamina I neurons contain GluR2, GluR3, and GluR4, but not GluR1. This is the first population of dorsal horn neurons for which the subunit composition of postsynaptic AMPArs has been determined.

Subunit composition determines physiological properties

\section{Glutamatergic inputs to the gephyrin-coated neurons}

We have previously identified these cells by the presence of numerous gephyrin puncta, which represent inhibitory axosomatic and axodendritic synapses (Puskár et al., 2001). Here, we show that cells of this type receive a very large number of contacts from VGLUT2-immunoreactive boutons and that these were far more numerous than those between VGLUT2 boutons and large multipolar NK1r-immunoreactive lamina I neurons. Because the VGLUT2 contacts on the gephyrincoated cells were associated with GluR4-containing puncta, we can be confident that these represent glutamatergic synapses. This method of identifying synaptic contacts is far less labor intensive than electron microscopy, and therefore allows a much larger sample to be analyzed.

Although VGLUT2 is expressed by A $\delta$ nociceptive primary afferents in lamina I (Todd et al., 2003), results after CTb injection into the sciatic nerve indicate that these afferents are unlikely to be a major source of monosynaptic input to the gephyrincoated cells. The cells also received few contacts from CGRPimmunoreactive boutons [3-7/1000 $\mu \mathrm{m}^{2}$ on proximal and distal dendrites compared with $23 / 1000 \mu \mathrm{m}^{2}$ on the dendrites of NK1rimmunoreactive projection neurons (Todd et al., 2002)], suggesting that they do not have strong direct input from peptidergic primary afferents. Some non-peptidergic unmyelinated afferents terminate in lamina I (Dhaka et al., 2008) and may innervate the gephyrin-coated cells. However, there is no evidence that central terminals of these afferents express high levels of VGLUT2. The main source of the numerous VGLUT2-immunoreactive boutons that synapse onto the gephyrin-coated cells is likely to be excitatory interneurons in the dorsal horn because these express VGLUT2 (Todd et al., 2003; Alvarez et al., 2004; Cheng et al., 
2004; Maxwell et al., 2007; Schneider and Walker, 2007), and many of them give rise to substantial axonal arborizations in lamina I (Maxwell et al., 2007). Most of the excitatory input to these cells therefore probably arrives through polysynaptic pathways, and this differs from the arrangement for NK1r-expressing projection neurons, which receive a strong synaptic input from both peptidergic primary afferents (Todd et al., 2002) and local excitatory interneurons (Olave and Maxwell, 2003). At present, the types of interneuron presynaptic to the gephyrin-coated cells are not known, but these could include stalked/vertical cells in lamina II (Gobel, 1978; Lu and Perl, 2005). One consequence of the strong polysynaptic input to the gephyrin-coated cells is that it may widen the range of primary afferents that can activate them. Lu and Perl (2005) proposed that much of the A $\delta$ input to lamina I projection neurons is transmitted through vertical cells in lamina II, which is consistent with the report by Yasaka et al. (2007) that most vertical cells received monosynaptic $A \delta$ input. In addition, these polysynaptic inputs may be subjected to strong modulatory influences, for example by monoamines (Lu and Perl, 2007).

\section{Morphology and function of multipolar lamina I projection neurons}

As reported previously (Puskár et al., 2001), we found that most gephyrincoated lamina I cells were multipolar, and it has been shown that approximately one-third of NK1r-expressing lamina I projection neurons in the rat are also multipolar (Spike et al., 2003). The great majority of cells in both of these populations project to the $\mathrm{LPb}$ and most of those in each class $(87 \%$ of gephyrin-coated cells, $79 \%$ of multipolar NK1r-expressing cells) showed Fos immunoreactivity after subcutaneous injection of formalin (Puskár et al., 2001; Todd et al., 2002), consistent with the report that multipolar cells have nociceptive receptive fields (Han et al., 1998).

However, there are also important differences between the gephyrin-coated cells and NK1r-immunoreactive multipolar lamina I neurons. We showed previously that $~ 60 \%$ of multipolar NK1r projection neurons upregulated Fos in response to immersion of the ipsilateral hindlimb in water at $52^{\circ} \mathrm{C}$ for $20 \mathrm{~s}$. With the longer (45 s) stimulus used here, a higher proportion (85\%) of multipolar NK1rimmunoreactive lamina I neurons were Fos positive. However, with this stimulus, only $38 \%$ of gephyrin-coated neurons expressed Fos, and these cells were never strongly labeled. This suggests that, al-
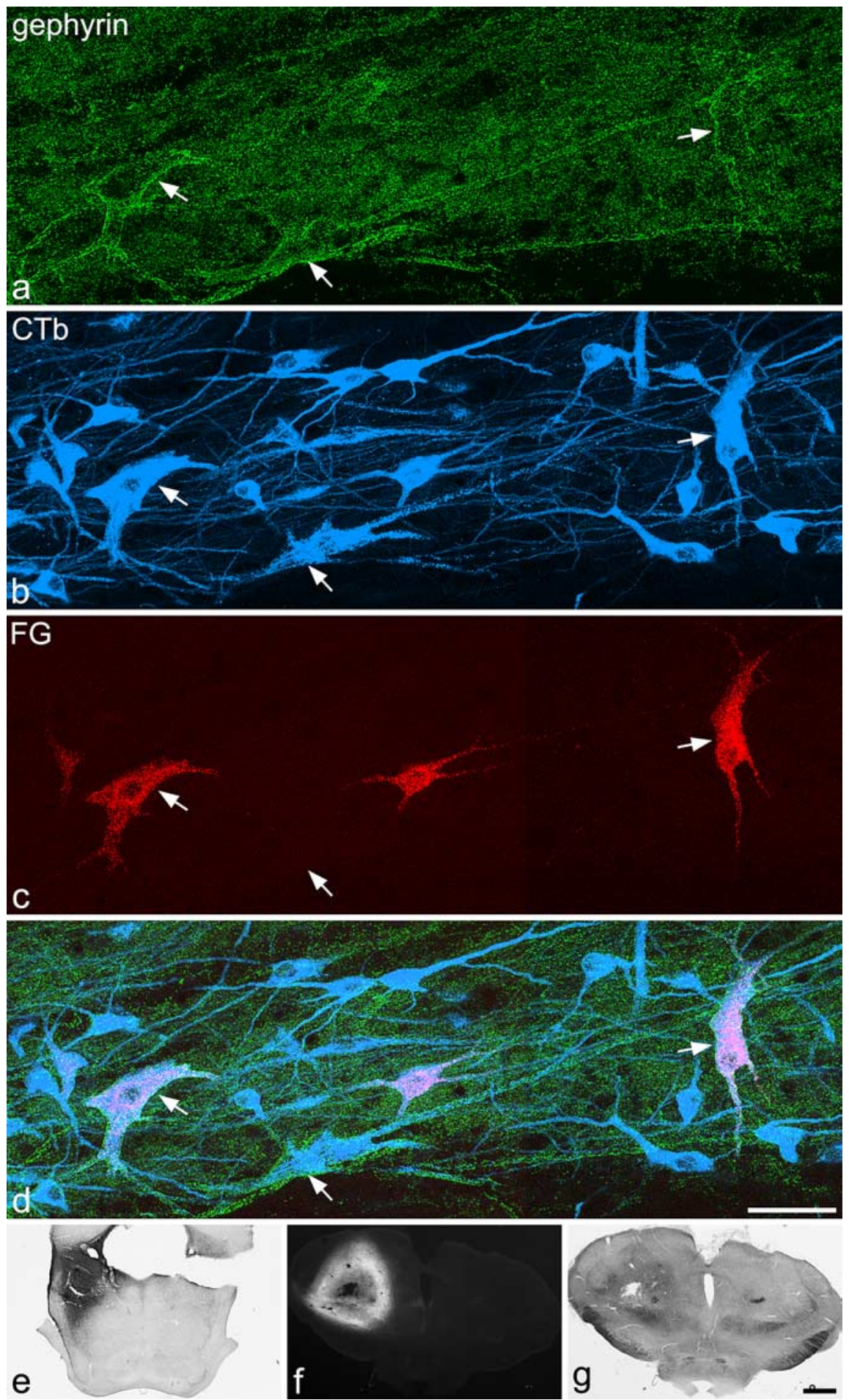

Figure 8. Retrograde labeling of large gephyrin-coated lamina I cells. $\boldsymbol{a}$ - $\boldsymbol{d}$ show part of a horizontal section through the contralateral side of the $L 5$ segment from a rat that had received injections of $(T b$ into the lateral parabrachial area and of Fluorogold centered on the $\mathrm{PO} T$ nucleus of the thalamus. $\boldsymbol{a}$ - $\boldsymbol{d}$ have been scanned to reveal gephyrin (green), $\mathrm{CTb}$ (blue), and Fluorogold (FG, red). This field contains three of the large gephyrin-coated cells (arrows). All of these are retrogradely labeled with $\mathrm{CT}$, as are numerous other smaller neurons in lamina I. Although only a small number of cells are labeled with Fluorogold, these include two of the gephyrin-coated cells (the ones on the left and right of the field). $\boldsymbol{e}$, The (Tb injection site. $\boldsymbol{f}, \boldsymbol{g}$, Epifluorescent and bright-field micrographs through the thalamic injection site (interaural $\sim 4$.2). $\boldsymbol{a}-\boldsymbol{d}$ are projections of 15 optical sections at $1 \mu \mathrm{mz}$-spacing. Scale bars: $\boldsymbol{a}-\boldsymbol{d}, 50 \mu \mathrm{m} ; \boldsymbol{e}-\boldsymbol{g}, 1 \mathrm{~mm}$.

though some are activated by noxious heating, this is a relatively ineffective stimulus for the gephyrin-coated cells. Our results support the suggestion that there is a functional/morphological correlation, because virtually all of the large gephyrin-coated neurons are 
multipolar. However, they show that the situation is more complex than that proposed by Han et al. (1998), because there are at least two classes of multipolar neuron in lamina I that differ in NK1r expression, synaptic inputs, and responses to noxious stimuli.

We have estimated that there are $\sim 6200$ lamina I neurons/ side in the rat L4 segment, of which $\sim 400(6 \%)$ are projection cells (Spike et al., 2003; Al-Khater et al., 2008). However, the number of spinothalamic neurons in this lamina is far lower (Lima and Coimbra, 1988; Burstein et al., 1990; Marshall et al., 1996). We have reported recently that $\mathrm{L} 4$ contains $\sim 15$ lamina I spinothalamic cells per side (Al-Khater et al., 2008), and in this study we found a similar number (mean of 17.6) in L5. Therefore, although the gephyrin-coated neurons make up only $0.2 \%$ of the total neuronal population and $\sim 2.5 \%$ of projection neurons in lamina I, they constitute a much higher proportion $(\sim 18 \%)$ of the spinothalamic population. Given the importance of the spinothalamic tract, it is likely that, despite the small number of these cells, they play a significant role in transmission of nociceptive information to cortical areas involved in pain perception. Because these cells lack NK1r, they will survive intrathecal treatment with substance $P$ conjugated to saporin (Mantyh et al., 1997) and may therefore contribute to the normal responses to acute noxious stimuli that are observed in this model.

\section{References}

Al-Khater KM, Kerr R, Todd AJ (2008) A quantitative study of spinothalamic neurons in laminae I, III and IV in lumbar and cervical segments of the rat spinal cord. J Comp Neurol 511:1-18.

Alvarez FJ, Villalba RM, Zerda R, Schneider SP (2004) Vesicular glutamate transporters in the spinal cord, with special reference to sensory primary afferent synapses. J Comp Neurol 472:257-280.

Burstein R, Dado RJ, Giesler GJ Jr (1990) The cells of origin of the spinothalamic tract of the rat: a quantitative reexamination. Brain Res 511:329-337.

Cheng L, Arata A, Mizuguchi R, Qian Y, Karunaratne A, Gray PA, Arata S, Shirasawa S, Bouchard M, Luo P, Chen CL, Busslinger M, Goulding M, Onimaru H, Ma Q (2004) Tlx3 and Tlx1 are post-mitotic selector genes determining glutamatergic over GABAergic cell fates. Nat Neurosci 7:510-517.

Dhaka A, Earley TJ, Watson J, Patapoutian A (2008) Visualizing cold spots: TRPM8-expressing sensory neurons and their projections. J Neurosci 28:566-575.

Esteban JA, Shi SH, Wilson C, Nuriya M, Huganir RL, Malinow R (2003) PKA phosphorylation of AMPA receptor subunits controls synaptic trafficking underlying plasticity. Nat Neurosci 6:136-143.

Galan A, Laird JM, Cervero F (2004) In vivo recruitment by painful stimuli of AMPA receptor subunits to the plasma membrane of spinal cord neurons. Pain 112:315-323.

Gauriau C, Bernard JF (2004) A comparative reappraisal of projections from the superficial laminae of the dorsal horn in the rat: the forebrain. J Comp Neurol 468:24-56.

Gobel S (1978) Golgi studies of the neurons in layer II of the dorsal horn of the medulla (trigeminal nucleus caudalis). J Comp Neurol 180:395-413.

Han ZS, Zhang ET, Craig AD (1998) Nociceptive and thermoreceptive lamina I neurons are anatomically distinct. Nat Neurosci 1:218-225.

Ju G, Hökfelt T, Brodin E, Fahrenkrug J, Fischer JA, Frey P, Elde RP, Brown JC (1987) Primary sensory neurons of the rat showing calcitonin generelated peptide immunoreactivity and their relation to substance P-, somatostatin-, galanin-, vasoactive intestinal polypeptide- and cholecystokinin-immunoreactive ganglion cells. Cell Tissue Res 247:417-431.

Katano T, Furue H, Okuda-Ashitaka E, Tagaya M, Watanabe M, Yoshimura M, Ito S (2008) N-ethylmaleimide-sensitive fusion protein (NSF) is involved in central sensitization in the spinal cord through GluR2 subunit composition switch after inflammation. Eur J Neurosci 27:3161-3170.

Larsson M, Broman J (2008) Translocation of GluR1-containing AMPA receptors to a spinal nociceptive synapse during acute noxious stimulation. J Neurosci 28:7084-7090.
Lawson SN, Crepps BA, Perl ER (1997) Relationship of substance P to afferent characteristics of dorsal root ganglion neurones in guinea-pig. J Physiol 505:177-191.

Lima D, Coimbra A (1988) The spinothalamic system of the rat: structural types of retrogradely labelled neurons in the marginal zone (lamina I). Neuroscience 27:215-230.

Lu Y, Perl ER (2005) Modular organization of excitatory circuits between neurons of the spinal superficial dorsal horn (laminae I and II). J Neurosci 25:3900-3907.

Lu Y, Perl ER (2007) Selective action of noradrenaline and serotonin on neurones of the spinal superficial dorsal horn in the rat. J Physiol 582:127-136.

Mantyh PW, DeMaster E, Malhotra A, Ghilardi JR, Rogers SD, Mantyh CR, Liu H, Basbaum AI, Vigna SR, Maggio JE (1995) Receptor endocytosis and dendrite reshaping in spinal neurons after somatosensory stimulation. Science 268:1629-1632.

Mantyh PW, Rogers SD, Honore P, Allen BJ, Ghilardi JR, Li J, Daughters RS, Lappi DA, Wiley RG, Simone DA (1997) Inhibition of hyperalgesia by ablation of lamina I spinal neurons expressing the substance P receptor. Science 278:275-279.

Marshall GE, Shehab SA, Spike RC, Todd AJ (1996) Neurokinin-1 receptors on lumbar spinothalamic neurons in the rat. Neuroscience 72:255-263.

Maxwell DJ, Belle MD, Cheunsuang O, Stewart A, Morris R (2007) Morphology of inhibitory and excitatory interneurons in superficial laminae of the rat dorsal horn. J Physiol 584:521-533.

Nagy GG, Al-Ayyan M, Andrew D, Fukaya M, Watanabe M, Todd AJ (2004) Widespread expression of the AMPA receptor GluR2 subunit at glutamatergic synapses in the rat spinal cord and phosphorylation of GluR1 in response to noxious stimulation revealed with an antigen-unmasking method. J Neurosci 24:5766-5777.

Olave MJ, Maxwell DJ (2003) Neurokinin-1 projection cells in the rat dorsal horn receive synaptic contacts from axons that possess $\alpha 2 \mathrm{C}$-adrenergic receptors. J Neurosci 23:6837-6846.

Oliveira AL, Hydling F, Olsson E, Shi T, Edwards RH, Fujiyama F, Kaneko T, Hökfelt T, Cullheim S, Meister B (2003) Cellular localization of three vesicular glutamate transporter mRNAs and proteins in rat spinal cord and dorsal root ganglia. Synapse 50:117-129.

Polgár E, Shehab SA, Watt C, Todd AJ (1999) GABAergic neurons that contain neuropeptide $\mathrm{Y}$ selectively target cells with the neurokinin 1 receptor in laminae III and IV of the rat spinal cord. J Neurosci 19:2637-2646.

Polgár E, Gray S, Riddell JS, Todd AJ (2004) Lack of evidence for significant neuronal loss in laminae I-III of the spinal dorsal horn of the rat in the chronic constriction injury model. Pain 111:144-150.

Polgár E, Thomson S, Maxwell DJ, Al-Khater K, Todd AJ (2007) A population of large neurons in laminae III and IV of the rat spinal cord that have long dorsal dendrites and lack the neurokinin 1 receptor. Eur J Neurosci 26:1587-1598.

Polgár E, Watanabe M, Hartmann B, Grant SG, Todd AJ (2008) Expression of AMPA receptor subunits at synapses in laminae I-III of the rodent spinal dorsal horn. Mol Pain 4:5.

Ptak K, Burnet H, Blanchi B, Sieweke M, De Felipe C, Hunt SP, Monteau R, Hilaire G (2002) The murine neurokinin NK1 receptor gene contributes to the adult hypoxic facilitation of ventilation. Eur J Neurosci 16:2245-2252.

Puskár Z, Polgár E, Todd AJ (2001) A population of large lamina I projection neurons with selective inhibitory input in rat spinal cord. Neuroscience 102:167-176.

Schneider SP, Walker TM (2007) Morphology and electrophysiological properties of hamster spinal dorsal horn neurons that express VGLUT2 and enkephalin. J Comp Neurol 501:790-809.

Spike RC, Puskár Z, Andrew D, Todd AJ (2003) A quantitative and morphological study of projection neurons in lamina I of the rat lumbar spinal cord. Eur J Neurosci 18:2433-2448.

Todd AJ, Spike RC, Polgár E (1998) A quantitative study of neurons which express neurokinin- 1 or somatostatin $\mathrm{sst}_{2 \mathrm{a}}$ receptor in rat spinal dorsal horn. Neuroscience 85:459-473.

Todd AJ, McGill MM, Shehab SA (2000) Neurokinin 1 receptor expression by neurons in laminae I, III and IV of the rat spinal dorsal horn that project to the brainstem. Eur J Neurosci 12:689-700.

Todd AJ, Puskar Z, Spike RC, Hughes C, Watt C, Forrest L (2002) Projection neurons in lamina I of rat spinal cord with the neurokinin 1 receptor 
are selectively innervated by substance P-containing afferents and respond to noxious stimulation. J Neurosci 22:4103-4113.

Todd AJ, Hughes DI, Polgár E, Nagy GG, Mackie M, Ottersen OP, Maxwell DJ (2003) The expression of vesicular glutamate transporters VGLUT1 and VGLUT2 in neurochemically defined axonal populations in the rat spinal cord with emphasis on the dorsal horn. Eur J Neurosci 17:13-27.

Todd AJ, Spike RC, Young S, Puskár Z (2005) Fos induction in lamina I projection neurons in response to noxious thermal stimuli. Neuroscience 131:209-217.

Watanabe M, Fukaya M, Sakimura K, Manabe T, Mishina M, Inoue Y (1998) Selective scarcity of NMDA receptor channel subunits in the stratum lucidum (mossy fibre-recipient layer) of the mouse hippocampal CA3 subfield. Eur J Neurosci 10:478-487.

Yasaka T, Kato G, Furue H, Rashid MH, Sonohata M, Tamae A, Murata Y,
Masuko S, Yoshimura M (2007) Cell-type-specific excitatory and inhibitory circuits involving primary afferents in the substantia gelatinosa of the rat spinal dorsal horn in vitro. J Physiol 581:603-618.

Yoshimura M, Jessell T (1990) Amino acid-mediated EPSPs at primary afferent synapses with substantia gelatinosa neurones in the rat spinal cord. J Physiol 430:315-335.

Yoshimura M, Nishi S (1992) Excitatory amino acid receptors involved in primary afferent-evoked polysynaptic EPSPs of substantia gelatinosa neurons in the adult rat spinal cord slice. Neurosci Lett 143:131-134.

Zhang ET, Craig AD (1997) Morphology and distribution of spinothalamic lamina I neurons in the monkey. J Neurosci 17:3274-3284.

Zhang ET, Han ZS, Craig AD (1996) Morphological classes of spinothalamic lamina I neurons in the cat. J Comp Neurol 367:537-549. 